\title{
Revised stratigraphy of the lower Cenozoic succession of the Greater Indus Basin in Pakistan
}

\author{
JAWAD AFZAL ${ }^{1,2, *}$, MARK WILLIAMS ${ }^{1} \&$ RICHARD J. ALDRIDGE $^{1}$ \\ ${ }^{1}$ Department of Geology, University of Leicester, Leicester LE1 7RH, UK \\ ${ }^{2}$ National Centre of Excellence in Geology, University of Peshawar, Pakistan \\ "Corresponding author (e-mail: ja136@le.ac.uk)
}

\begin{abstract}
A refined stratigraphy for the lower Cenozoic succession of the Greater Indus Basin in Pakistan is presented. This region preserves an important East Tethyan marine succession through the Paleocene-Eocene, but its interpretation in terms of regional (tectonic) and global (climatic) effects has been inhibited by poor stratigraphy. Established dinoflagellate, nannofossil, planktonic foraminiferal and shallow benthonic foraminiferal biostratigraphical data for the Greater Indus Basin in Pakistan are collated, reinterpreted (where necessary) and correlated with the global standard chronostratigraphy and biostratigraphy of the early Palaeogene. Inter-regional stratigraphical correlations for the Upper Indus Basin and Lower Indus Basin are resolved. Age-diagnostic larger benthonic foraminifera from the Late Paleocene Lockhart Formation are illustrated. These collective biostratigraphical data provide a means of interpreting the lithostratigraphy and physical stratigraphical relationships of the Palaeogene succession in terms of the interplay between local tectonics (India-Asia collision) and global sea-level change. The timing of the Tethys closure, initial and final contact of the Indian-Asian plates, and dispersal of land mammals on the Indian Plate are discussed and correlated in the stratigraphical record of the basin. J. Micropalaeontol. 28(1): 7-23, May 2009.
\end{abstract}

KEYWORDS: Palaeogene, lithostratigraphy, biostratigraphy, Greater Indus Basin, Pakistan

\section{INTRODUCTION}

The stratigraphy of the fossiliferous lower Cenozoic sediments of the Greater Indus Basin as it is represented in Pakistan has been a subject of research since the late nineteenth century. The early studies, summarized in Table 1, led to a detailed record of the lithology, biostratigraphy and palaeoenvironments, which was compiled and published by the Geological Survey of Pakistan (GSP) (Shah, 1977). This publication incorporated well-illustrated reference sections from parts of the Greater Indus Basin in Pakistan. Recent discoveries of new stratigraphical sections, combined with new published data and information from extensive petroleum exploration in the region, have provided new insights into the lithostratigraphical and biostratigraphical framework. This wealth of data has, however, led to highly variable application of stratigraphical names and a variety of conflicting stratigraphical interpretations.

The aims of this paper are to: (a) review published and unpublished lithostratigraphical and biostratigraphical information throughout the Greater Indus Basin in Pakistan; (b) provide a modern stratigraphical nomenclature for the rock units published by the Geological Survey of Pakistan (Shah, 1977) in the light of newly available evidence; and (c) discuss the palaeogeography and depositional systems of these stratigraphical units in the light of this refined stratigraphical nomenclature.

\section{GEOLOGICAL SETTING}

The lower Cenozoic succession of the Greater Indus Basin represents the northwestern continental shelf margin setting of the Indian Plate (Figs 1, 2). The basin extends over most of eastern Pakistan and the westernmost parts of India, covering an area of about $873000 \mathrm{~km}^{2}$ (Wandrey et al., 2004) and comprises several sub-basins, plateaux and ranges (e.g. Shah, 1977). The sedimentary rock succession was deposited in the eastern part of the Tethyan Ocean. In this paper, we deal with the stratigraphy of the basin as it is represented in Pakistan. The
Greater Indus Basin in Pakistan is traditionally divided into two sub-basins referred to as the Upper Indus Basin and the Lower Indus Basin (Figs 1, 2). The Upper Indus Basin, also known as the Kohat-Potwar Range, forms the northernmost element of the Greater Indus Basin in Pakistan and is bounded to the north by the Kala Chitta Range. The Salt Range composite orocline forms the southern limit (Figs 1, 2A), while the Kurram thrust fault marks its western limit. The Pezu wrench fault separates the Upper Indus Basin from the Lower Indus Basin. Lower Cenozoic sediments of the Upper Indus Basin are exposed at surface along east-west-trending fold-and-thrust belts of the Kohat, Hazara, Banu and Wazirestan areas and the Kala Chitta, Surghar and Salt ranges (Fig. 2A). The Lower Indus Basin is constrained by the Mari-Khandkot-Jaisalmer High to the east, and the Kirthar Fold Belt and Foredeep to the west (Figs 1, 2B), while the Jacobabad High is sometimes used to separate the Lower and Upper basins (e.g. Kemal et al., 1992), with the Upper Basin north of the Sargodha High. The tectonic history and stratigraphical framework of the region are influenced strongly by collision of the Indo-Pakistan and Asian plates (Beck et al., 1995; Butler, 1995; Hodges, 2000). Indeed, the lower Cenozoic stratigraphy of the Greater Indus Basin in Pakistan is critical in terms of assessing India-Asia collision, as estimates of the timing of the initial collision vary from $65 \mathrm{Ma}$ to 45 Ma (Searle et al., 1987; Dewey et al., 1989; Le Pichon et al., 1992; Beck et al., 1995; Rowley, 1996).

The Indo-Pakistan plate in the north and northwestern part of Pakistan was subject to subduction and orogenic processes at about $55 \mathrm{Ma}$ at the Paleocene-Eocene boundary (de Sigoyer et al., 2000; Qayyum et al., 2001; Khan \& Srivastava, 2006). A combination of detailed age dating and palaeobathymetric determinations indicates significant basin uplift and erosion at end Cretaceous and end Eocene times, the latter coinciding with the closure of Neo-Tethys (Wakefield \& Monteil, 2002). During the collision, the existing Late Cretaceous Tethyan sediments 


\begin{tabular}{ll}
\hline Author & Research undertaken \\
\hline Blanford (1879) & $\begin{array}{l}\text { Geology of western Sind } \\
\text { The Eocene beds of the Salt Range } \\
\text { Davies \& Pinfold (1937) } \\
\text { The Ranikot beds at Thal } \\
\text { The geology of standard sections in the western Punjab and in the } \\
\text { Eames (1952) }\end{array}$ \\
$\begin{array}{l}\text { Kohat District, Pakistan } \\
\text { Lithostratigraphy of the Kohat-Potwar Province, Indus Basin }\end{array}$ \\
Fatmi (1974) & $\begin{array}{l}\text { Foraminifera of the Ranikot and the Laki of the Salt Range, Pakistan } \\
\text { Stratigraphy of the Bannu and Dera Ismail Khan areas, Pakistan }\end{array}$ \\
Hemphill \& Kidwai (1973) & $\begin{array}{l}\text { Geology of part of West Pakistan } \\
\text { Pelagic foraminifera of the Paleocene-Eocene of Rakhi Nala, Pakistan }\end{array}$ \\
Hunting Survey Corporation (1960) & $\begin{array}{l}\text { Geology of Southeast Hazara, Pakistan } \\
\text { Latif (1964) }\end{array}$ \\
Latif (1970) & $\begin{array}{l}\text { Geology of the Hazara and the Black Mountain } \\
\text { Latif (1976) }\end{array}$ \\
Middlemiss (1896) & $\begin{array}{l}\text { Foraminiferal biostratigraphy of the Cretaceous-Eocene succession in } \\
\text { India-Pakistan }\end{array}$ \\
Nagappa (1959) & Geology of the upper Punjab \\
Stratigraphy of the Lower Indus Basin \\
Waagen \& Wynne (1872) & Geology of Mari Hill Station, Punjab \\
Williams (1959) &
\end{tabular}

Table 1. List of key authors who have presented stratigraphical information for the Greater Indus Basin, Pakistan

accreted onto the eastern margin of the Indo-Pakistan plate and probably spilled over and spread across most of the Indo-Pakistan plate (Khan \& Srivastava, 2006). The Himalaya mountain chain is a direct result of this continental collision,

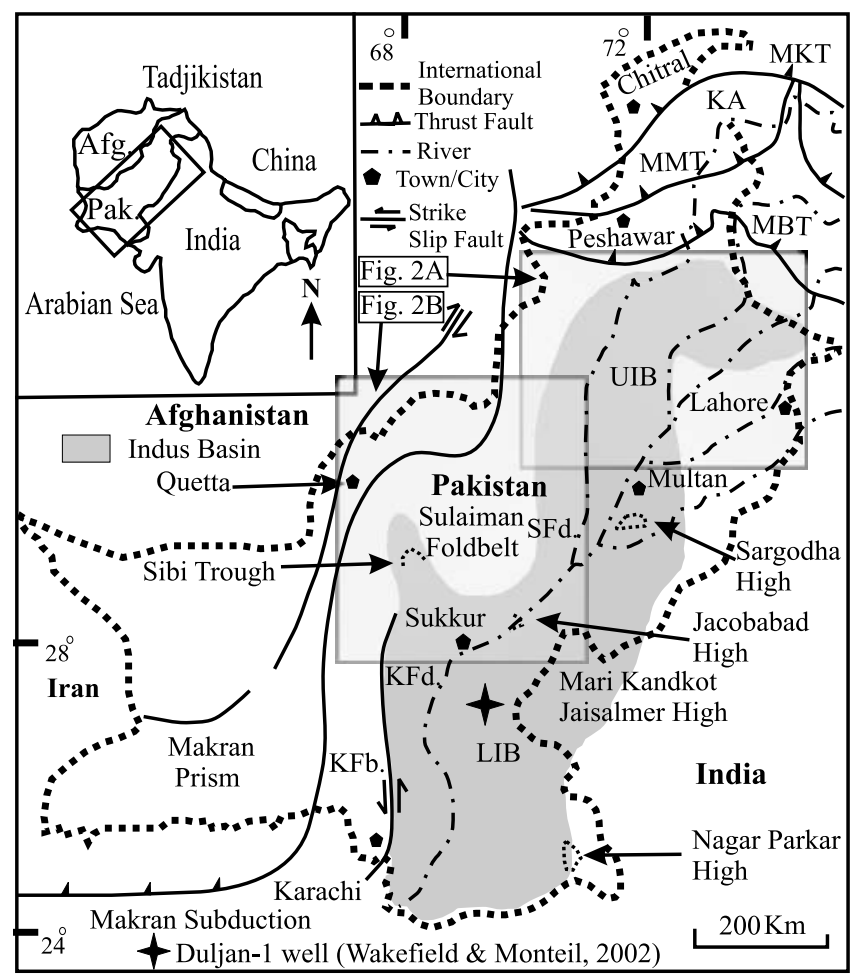

Fig. 1. Map of Pakistan, showing position of the Greater Indus Basin and major tectonic units (modified after Wakefield \& Monteil, 2002). MKT, Main Kohistan Thrust; MMT, Main Mantle Thrust; MBT, Main Boundary Thrust; KFb., Kirthar Foldbelt; KFd., Kirthar Foredeep; SFd., Sulaiman Foredeep; KA, Kohistan Arc; UIB, Upper Indus Basin; LIB, Lower Indus Basin. during which the fold-and-thrust belts of western and northwestern Pakistan were initiated (Le Fort, 1996).

\section{STRATIGRAPHY OF THE GREATER INDUS BASIN IN PAKISTAN}

The rocks of lower Cenozoic age in the Greater Indus Basin in Pakistan are remarkably varied in lithology and thickness, but mainly consist of marine limestone and shale with subordinate sandstone and non-marine red beds, gypsum, anhydrite, salt and coal (Shah, 1977). Terrestrial emergence at the end of the Paleocene, followed by marine submergence in the Early Eocene (Shah, 1977), was succeeded by a short-lived regression at the close of late Early Eocene times, resulting in evaporites being deposited in the Kohat area (Nagappa, 1959). Following evaporite formation, a marine transgression at the start of the Middle Eocene affected a large area, including the western Kohat, the Lower Indus Basin, the Axial Belt and the Baluchistan Basin (Shah, 1977). During Middle and Late Eocene times different parts of Pakistan became emergent and this resulted in unconformities of varying magnitude (Shah, 1977).

A revised nomenclature for the stratigraphical units of the Greater Indus Basin in Pakistan was defined by the GSP, who compiled work from a number of authors (Shah, 1977). Subsequently published biostratigraphical work on calcareous nannofossils, dinoflagellates, planktonic and benthonic foraminifera (e.g. Köthe et al., 1988; Afzal \& Daniels, 1991; Butt, 1991; Weiss, 1993; Afzal, 1996; Jones, 1997; Akhtar \& Butt, 1999; Warraich et al., 2000; Afzal \& Butt, 2000; Raza, 2001a, b; Ferrandez-Canadell, 2002; Wakefield \& Monteil, 2002; Warraich \& Nishi, 2003; Sameeni \& Butt, 2004; Afzal et al., 2005; Siddiqui, 2006) is summarized here in order to update and, where necessary, modify lithostratigraphical and biostratigraphical designations for various stratigraphical units published by the GSP (Shah, 1977): see Figures 3 to 7. 


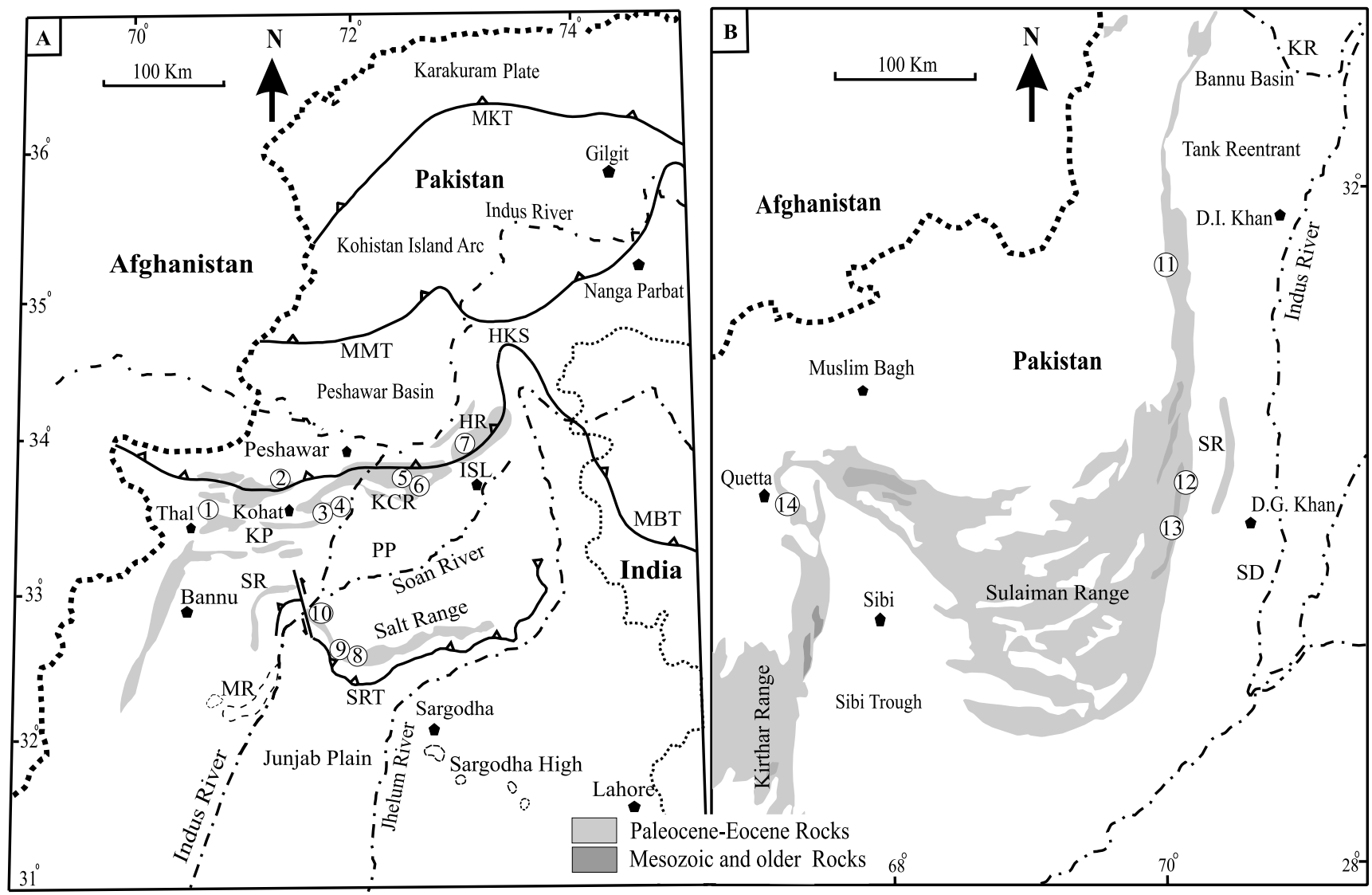

Fig. 2. (A) Map of the Upper Indus Basin showing distribution of Paleocene-Eocene sedimentary rocks and key stratigraphical sections (modified after Köthe et al., 1988). KP, Kohat Plateau; PP, Potwar Plateau; KCR, Kala Chitta Range; HR, Hazara Range; SR, Surghar Range; SRT, Salt Range Thrust; MR, Marwat Range; HKS, Hazara-Kashmir Syntaxis; ISL, Islamabad; 1, North of Hangu section; 2, Kotal Pass section; 3, Tarkhobi section; 4, Panoba section; 5, Burjianwala Laman; 6, Chak Dalla; 7, Bagnotar-Kuldana; 8, Patala Nala section; 9, Nammal Gorge section; 10, Khairabad section. (B) Map of part of the Lower Indus Basin showing distribution of Paleocene-Eocene sedimentary rocks and key stratigraphical sections (modified after Köthe et al., 1988). KR, Kurram River; SD, Sulaiman Depression; SR, Sulaiman Range; 11, Mughal Kot-Toi section; 12, Zinda Pir section; 13, Rakhi Nala section; 14, Muree Brewery section.

\section{THE UPPER INDUS BASIN}

The evolution of the lower Cenozoic stratigraphical nomenclature for the Upper Indus Basin is given in Table 2. An integrated dinoflagellate, nannofossil, shallow benthonic and planktonic foraminiferal biostratigraphy for the Upper Indus Basin, related to standard chronostratigraphy and biostratigraphy, is presented for the first time (Fig. 3). Biostratigraphical and lithostratigraphical evidence for the age of Paleocene-Eocene stratigraphical units from various parts of the Upper Indus Basin is shown in Figure 4 against global chronostratigraphy and biostratigraphy. The stratigraphical context for these units is discussed below.

\section{Sub-basins: Kohat area, Kala Chitta Range, Hazara Range, Salt Range, Surghar Range}

The Kohat area represents the northwestern part of the Upper Indus Basin and exposes a succession of Cenozoic rocks (Fig. 2A). The Kala Chitta Range marks the northern edge of the Potwar Plateau and merges northeasterly into the Hazara Range, representing the northeastern portion of the Upper Indus Basin (Fig. 2A). The Salt and Surghar ranges form the southern portion of the Upper Indus Basin. The Salt Range is an east-west-trending narrow mountain belt bounded by the Jhelum River to the east and the Indus River to the west (Fig. 2A). The Surghar Range is a north-south-trending mountain range separated from the Salt Range to the west by the Indus River and the strike-slip Kala Bagh Fault (Fig. 2A). Mesozoic and Cenozoic marine sediments of the Salt Range extend into the Surghar Range (Fig. 2A).

The Hangu Formation of Shah (1977) is the basal Cenozoic sedimentary unit in this region (Fig. 4). It comprises sandstone, siltstone and clays in the Kohat area, Kala Chitta and Hazara ranges (Shah, 1977), with argillaceous limestone beds in the Salt Range and also a coal-bearing horizon in the Surghar Range (Shah, 1977; Warwick et al., 1993). The formation unconformably overlies the Late Cretaceous Kawagarh Formation in most of the basin (Latif, 1976; Shah, 1977), but occasionally overlies Palaeozoic units in the Salt Range and Surghar Range (Shah, 1977). The Hangu Formation is unfossiliferous in the Kohat area, Kala Chitta and Hazara ranges (Latif, 1976; Shah, 1977; Weiss, 1993) and its chronostratigraphical position is based on regional geological context (Fig. 4). In the Salt Range, upper parts of the formation yield age-diagnostic foraminifera (Davies \& Pinfold, 1937; Haque, 1956; Weiss, 1993; Ferrandez-Canadell, 


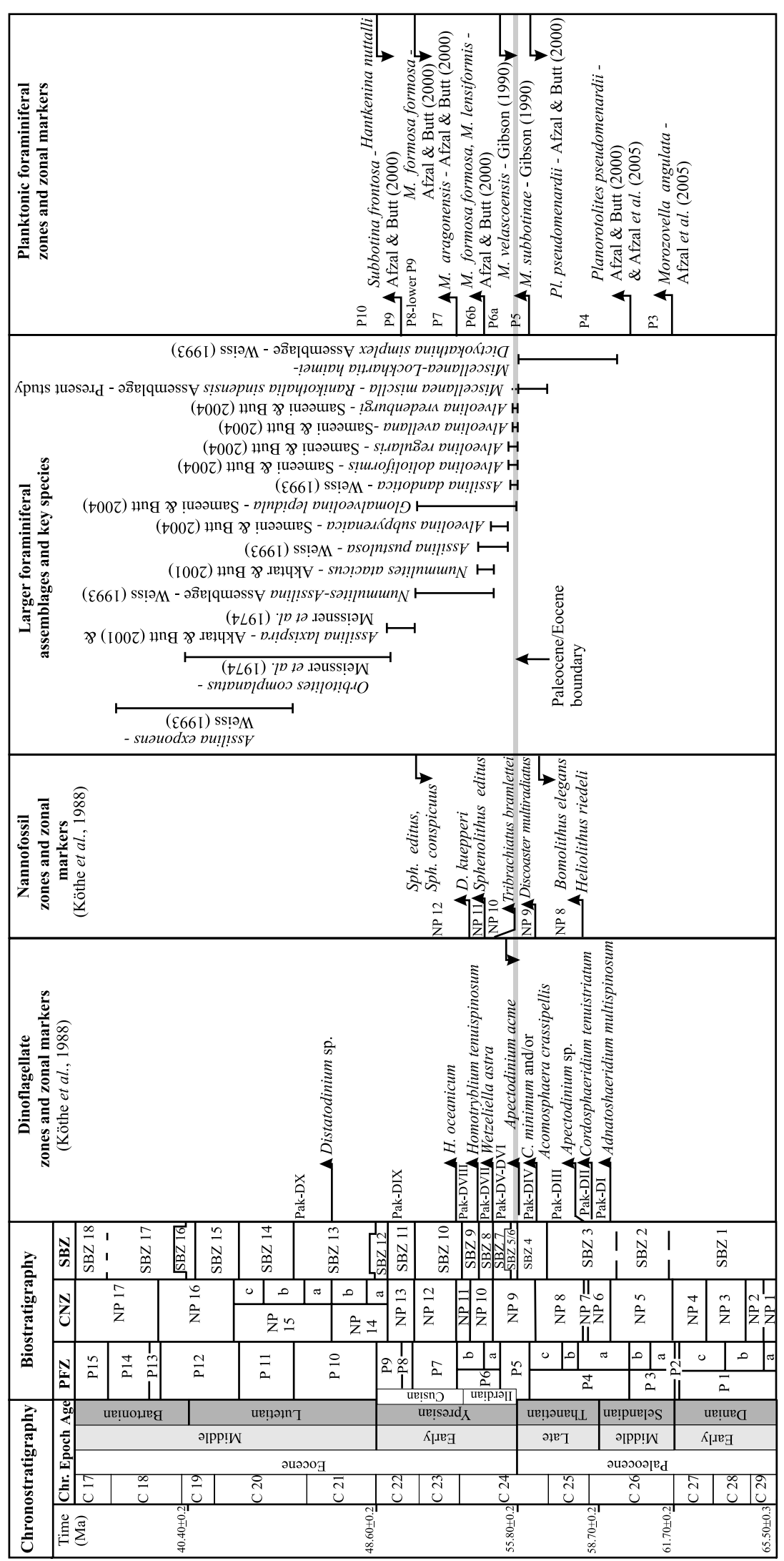

䒕

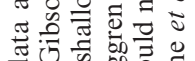
कृष 0 की चु

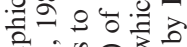

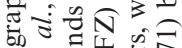

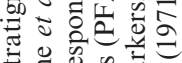
के 田 \& $\mathrm{N}$ 술류

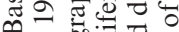

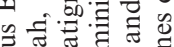
实近

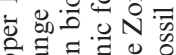

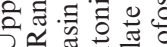
的

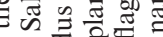

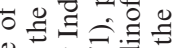

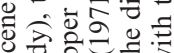

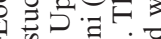
要

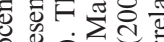
चै

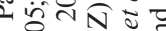

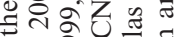
ㅎำ 施 通事:

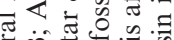

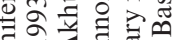
政

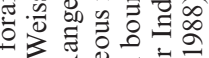

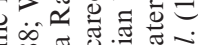

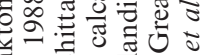
ज्ञ

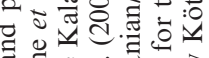

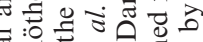

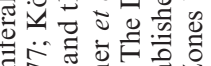
客守佘宇 పే 占志可导 . ప. 3

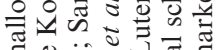
的

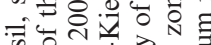
员 웜

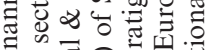

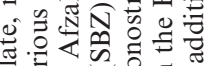

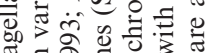

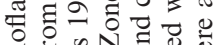

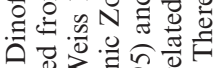

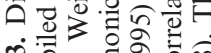
m

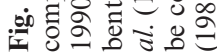



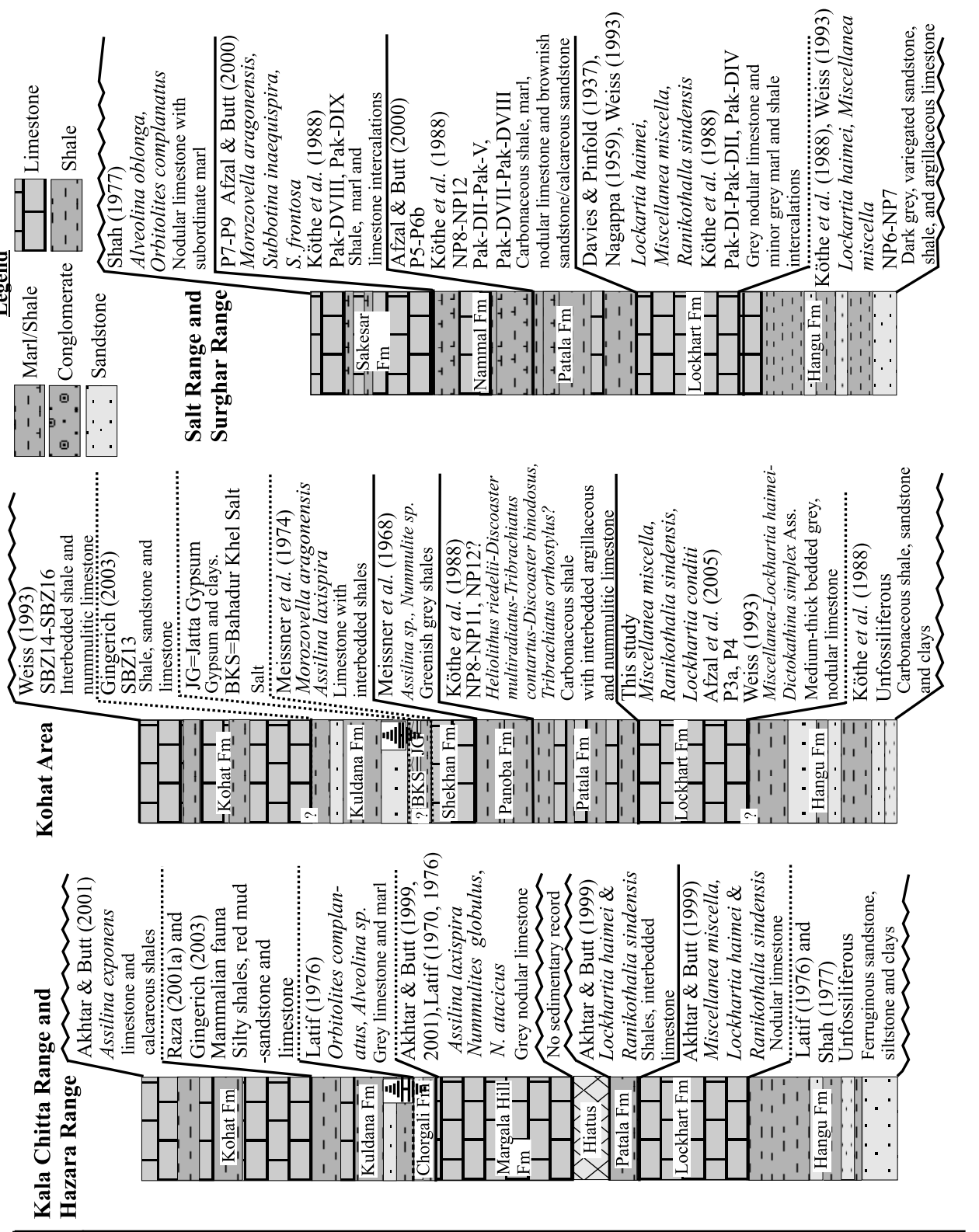

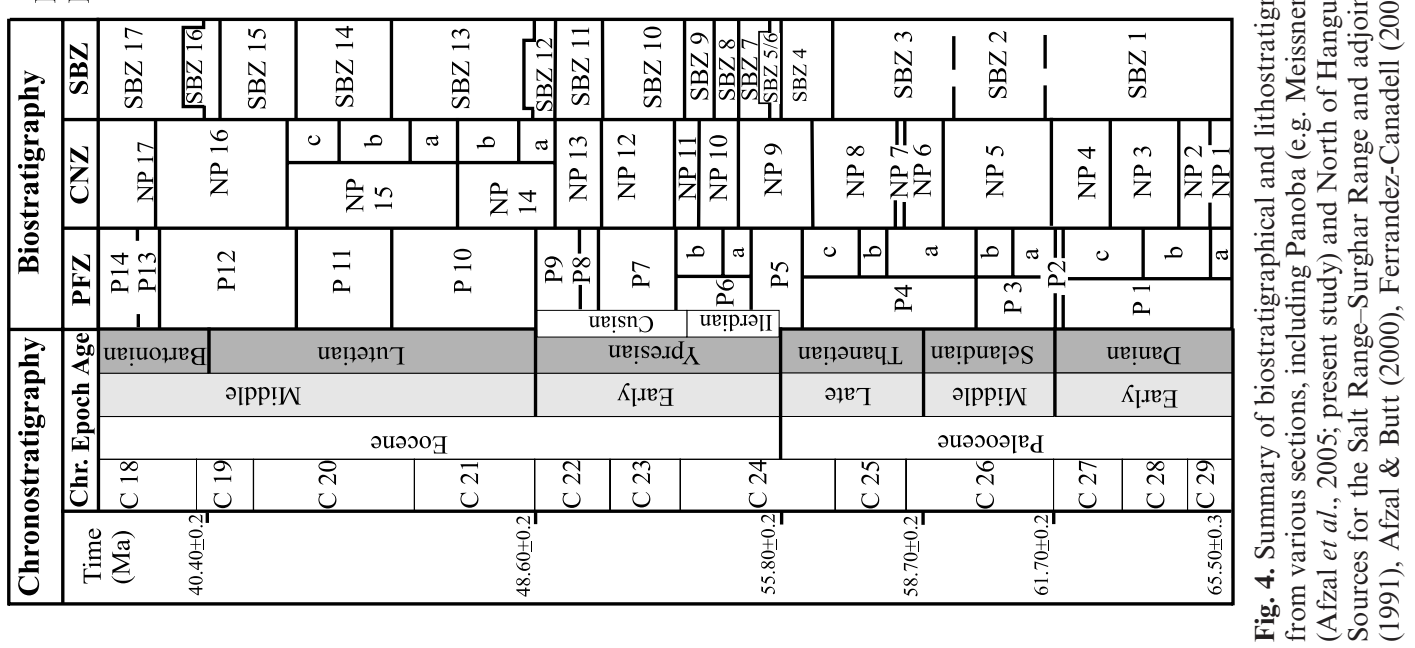




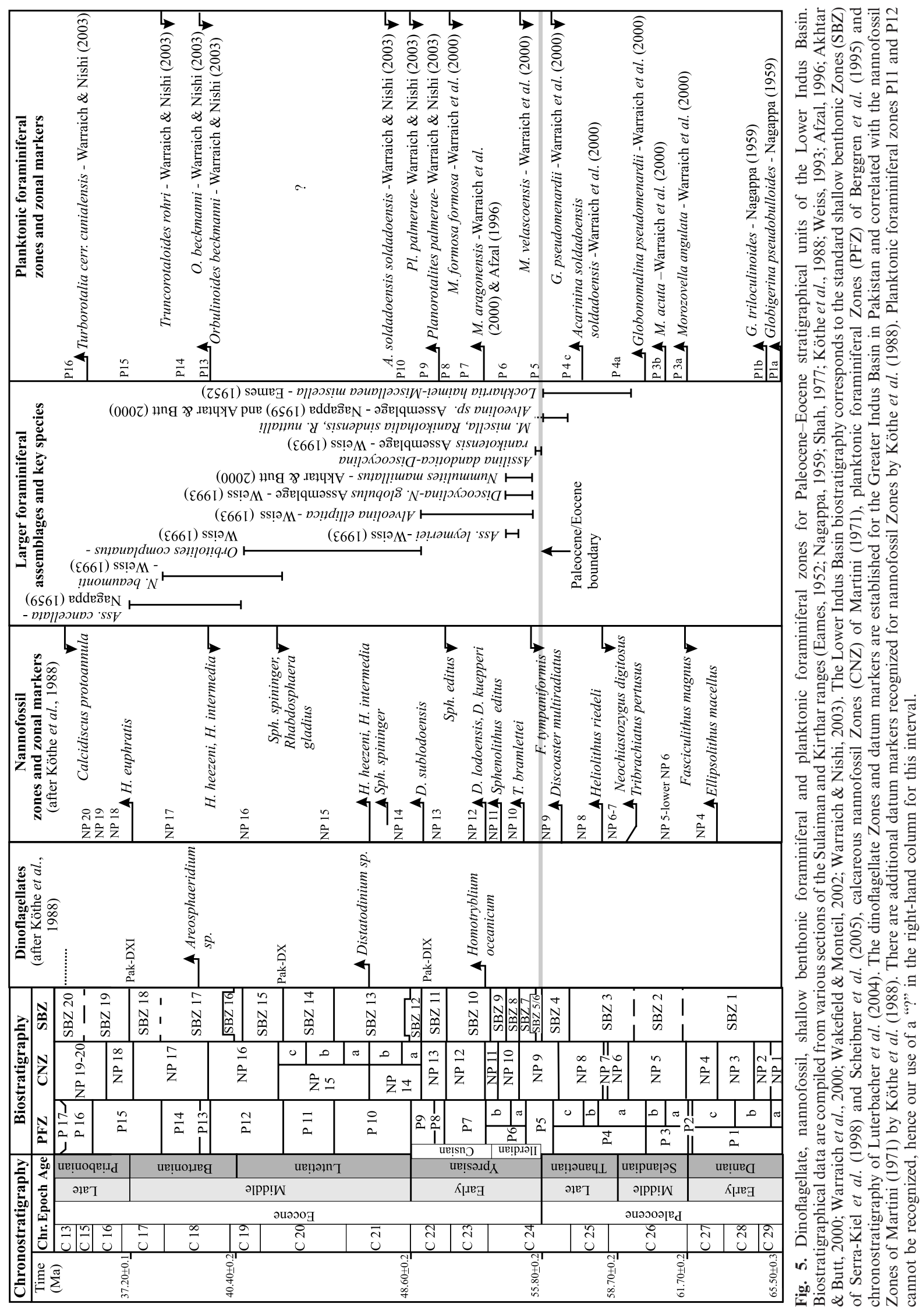




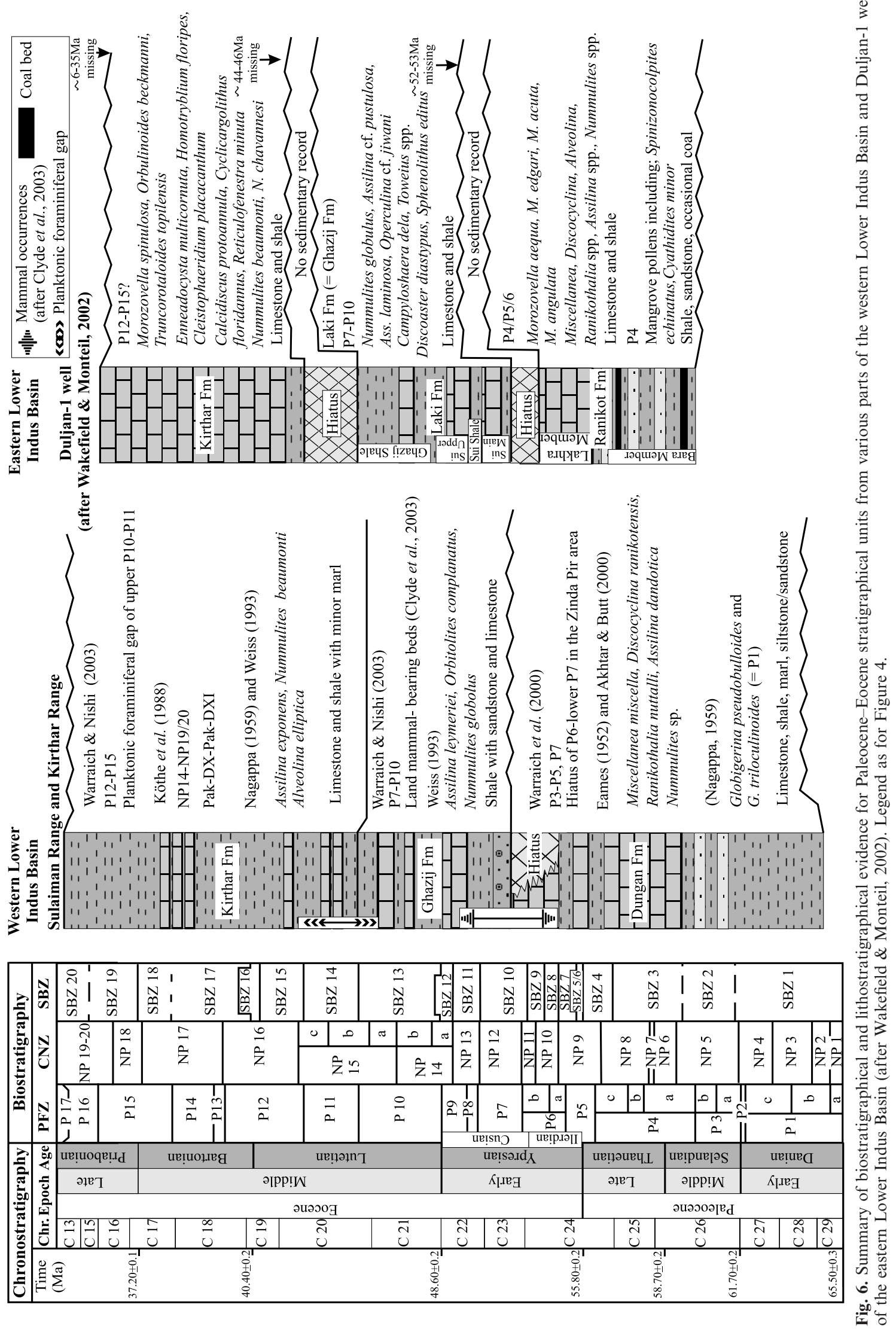


J. Afzal et al.

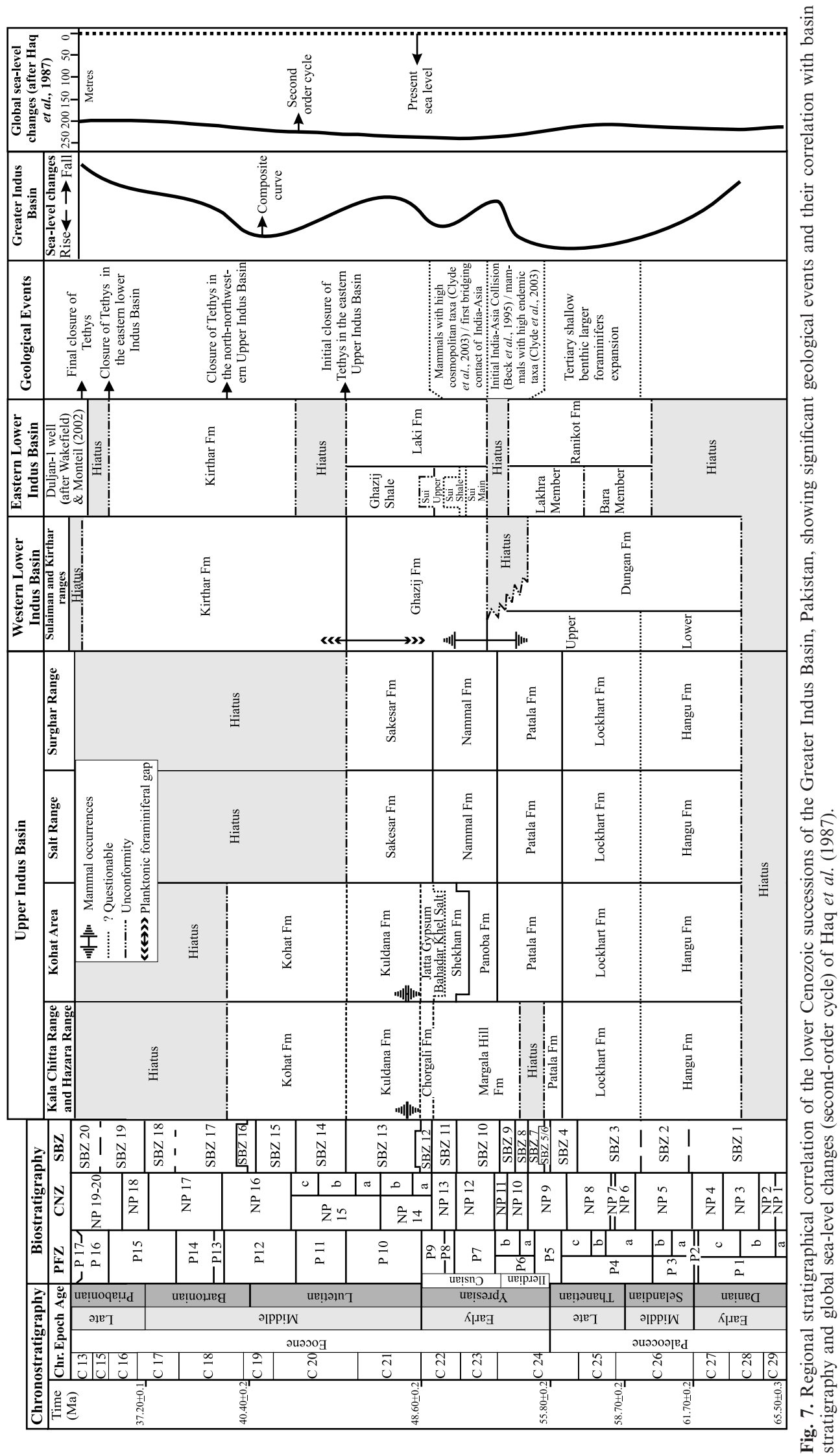




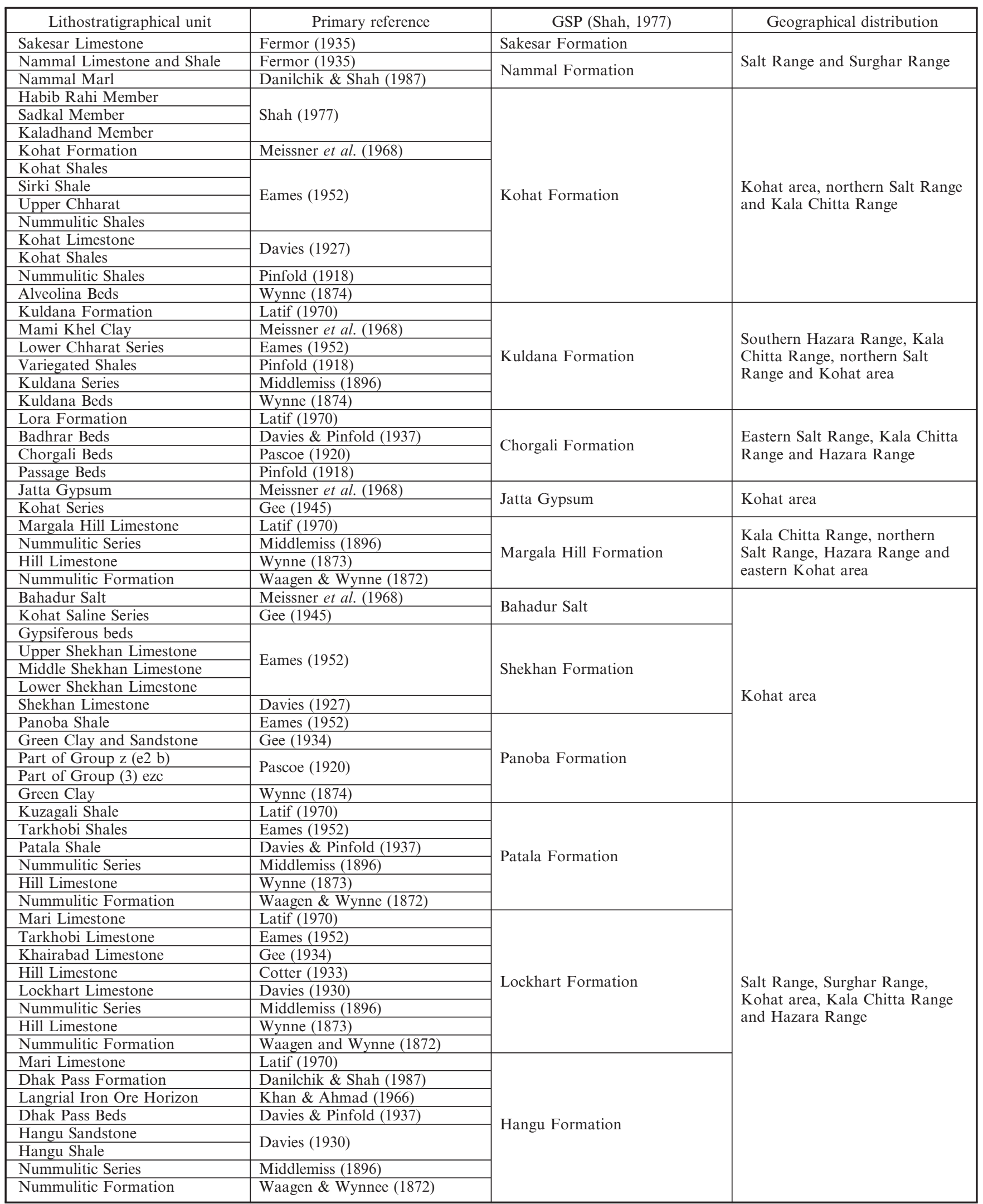

Table 2. Lithostratigraphical nomenclature for the Upper Indus Basin, Pakistan. 
2002), nannofossils (Köthe et al., 1988; Warwick et al., 1993) and dinoflagellates (Köthe et al., 1988), which are identical to biota reported from the overlying basal Lockhart Formation elsewhere in the basin (Fig. 4).

The Lockhart Formation consists of nodular limestone in the Kohat area, Kala Chitta and Hazara ranges (Latif, 1970, 1976; Fatmi, 1974; Shah, 1977; Akhtar \& Butt, 1999) and limestone and marl in the Salt and Surghar ranges (Shah, 1977). The Lockhart Formation yields abundant age-diagnostic larger benthonic foraminifera in the Kohat area (Weiss, 1993; present study), the Kala Chitta and Hazara ranges (Latif, 1970, 1976; Akhtar \& Butt, 1999) and the Salt Range (Davies \& Pinfold, 1937; Haque, 1956; Weiss, 1993). These occurrences and newly reported Miscellanea miscella, Ranikothalia sindensis, Lockhartia conditi, Lockhartia haimei and Operculina jiwani from the Kotal Pass, Kohat area, support maximum stratigraphical ranges through foraminiferal shallow benthonic Zones SBZ3SBZ4 (Serra-Kiel et al., 1998) (Pl. 1, figs 1-12). Planktonic foraminifera from the Kohat area (Afzal et al., 2005), dinoflagellates (= nannofossil Zones NP6-NP8 of Martini, 1971) from the Salt Range (Köthe et al., 1988) and nannofossils from the Surghar Range (Warwick et al., 1993) also support this biostratigraphical range (Figs 3, 4).

The Lockhart Formation is succeeded by shale, sandstone and marly limestone of the Patala Formation (Shah, 1977; Akhtar \& Butt, 1999). The occurrence of sandstone within the formation is restricted to the Salt and Surghar ranges (Shah, 1977; Gibson, 1990; Warwick et al., 1993) (Fig. 4). The Patala Formation in the Kala Chitta and Hazara ranges (Latif, 1970, 1976; Akhtar \& Butt, 1999) and the Salt Range (Haque, 1956; Weiss, 1993; Sameeni \& Butt, 2004) contains late Thanetian to early Ilerdian larger benthonic foraminiferal species, suggesting Zones SBZ4 to SBZ6 (Fig. 4). Age-diagnostic planktonic foraminiferal species from the Hazara Range, e.g. Globorotalia elongata [= Morozovella elongata $]$ and Globigerina soldadoensis [= Muricoglobigerina soldadoensis] (Latif, 1976), and from the Salt Range (Weiss, 1993), indicate the Morozovella velascoensisAcarinina soldadoensis Zone (= P4c-P5 Zones of Berggren et al., 1995). Planktonic foraminiferal Zones P5-P6b from the Salt Range (Afzal \& Butt, 2000) and Kohat area (Weiss, 1993) provide a stratigraphical range that extends across the Paleocene-Eocene boundary (Fig. 4). Identification of dinoflagellate Zones equivalent to NP8-NP11 from the Salt Range and nannofossil Zones NP8-NP12 from the Kohat area and the Salt Range (Köthe et al., 1988) support a late Thanetian-early Ypresian biostratigraphical age (Figs 3, 4). There have been inconsistencies in the logging and mapping of the Patala Formation and its boundaries have been placed differently by various workers (Gibson, 1990), which has led to varying stratigraphical interpretations. However, the regional stratigraphical framework suggests a maximum age of late Thanetian-early Ypresian (Figs 4, 7).

The Patala Formation is separated by an unconformity (upper P5-P6a) from the overlying nodular limestone and marl/shale of the Margala Hill Formation in the Kala Chitta and Hazara ranges (Latif, 1970, 1976; Shah, 1977; Akhtar \& Butt, 1999, 2001) (Fig. 4). In most of the Kohat area the Patala Formation is conformably overlain by greenish shales of the Panoba Formation, but in the Salt and Surghar ranges it is followed conformably by the marl/shale and limestone of the Nammal Formation (Shah, 1977) (Fig. 4).

The larger benthonic foraminifera from the Panoba Formation (Meissner et al., 1968, in Shah, 1977) indicate an age of SBZ10 (Fig. 4). The Margala Hill Formation yields larger benthonic foraminifera (Latif, 1970, 1976; Akhtar \& Butt, 1999, 2001), which support a biostratigraphical age through Zones SBZ8-SBZ11 (Fig. 4). The larger benthonic foraminifera and zonally important planktonic foraminiferal species from the Nammal Formation (Weiss, 1993; Afzal \& Butt, 2000; Sameeni \& Butt, 2004) suggest a P7-P9 age (Figs 3, 4). Köthe et al. (1988) also recorded the same biostratigraphical age based on the recognition of nannofossil Zones NP11-NP12 and of dinoflagellates equivalent to NP11-NP14.

The Panoba Formation is overlain by limestone and shale of the Shekhan Formation in the northern Kohat area, and by the Jatta Gypsum or Bahadur Khel Salt in the southwest Kohat area (Shah, 1977) (Fig. 4). Limestone and marl of the Chorgali Formation overlie the Margala Hill Formation in the Kala Chitta and Hazara ranges and Sakesar Formation in the eastern Salt Range (Shah, 1977). In the Surghar Range, limestone and marl of the Sakesar Formation conformably overlie the Nammal Formation and mark the end of marine deposition in this part of the basin, being overlain unconformably by non-marine molasse sediments of Miocene age (Shah, 1977).

The Shekhan Formation is barren of nannofossils and dinoflagellates (Köthe et al., 1988). The larger benthonic foraminifera indicate a late Ypresian age (= SBZ11) (Nagappa, 1959; Pascoe, 1963; Shah, 1977; Weiss, 1993). The occurrence of Assilina laxispira and the planktonic foraminifera Morozovella aragonensis and others is indicative of Zones P8-P9 (Meissner et al., 1974) (Figs 3, 4). The Shekhan Formation is overlain by unfossiliferous evaporitic deposits of the Bahadur Khel Salt and Jatta Gypsum (Meissner et al., 1974; Shah, 1977) (Fig. 4).

The Chorgali Formation in the Kala Chitta, Hazara and eastern Salt ranges yields age-diagnostic larger benthonic foraminifera from Zones SBZ11-SBZ12 (Latif, 1970, 1976; Shah, 1977; Sameeni \& Butt, 2004) (Fig. 4).

The shale and marl succession of the Kuldana Formation, which yields fossil mammals (Raza, 2001a), succeeds the Chorgali Formation in the Kala Chitta and Hazara ranges and the Bahadur Khel Salt and Jatta Gypsum in the Kohat area (Shah, 1977). On the basis of larger benthonic foraminifera from the Kala Chitta and Hazara ranges (Latif, 1970, 1976) and mammal faunas from different parts of the Kohat area and Kala Chitta Range (Raza, 2001a; Gingerich, 2003), the Kuldana Formation is assigned to Zone SBZ13 or older (Fig. 4). The shale and nummulitic limestone succession of the Kohat Formation overlies the Kuldana Formation in most of the Kohat area, Kala Chitta and Hazara ranges (Shah, 1977; Akhtar \& Butt, 1999, 2001).

The Kohat Formation marks the last episode of marine sedimentation in the Kohat area, Kala Chitta and Hazara ranges and is overlain by non-marine molasse sediments of the Miocene Murree Formation. The late Ypresian-Lutetian age assignment for the Kohat Formation given by Shah (1977) is based on molluscs (Eames, 1952) and larger benthonic foraminifera (see Meissner et al., 1968). The same biostratigraphical ages can be extracted from the foraminifera record of 


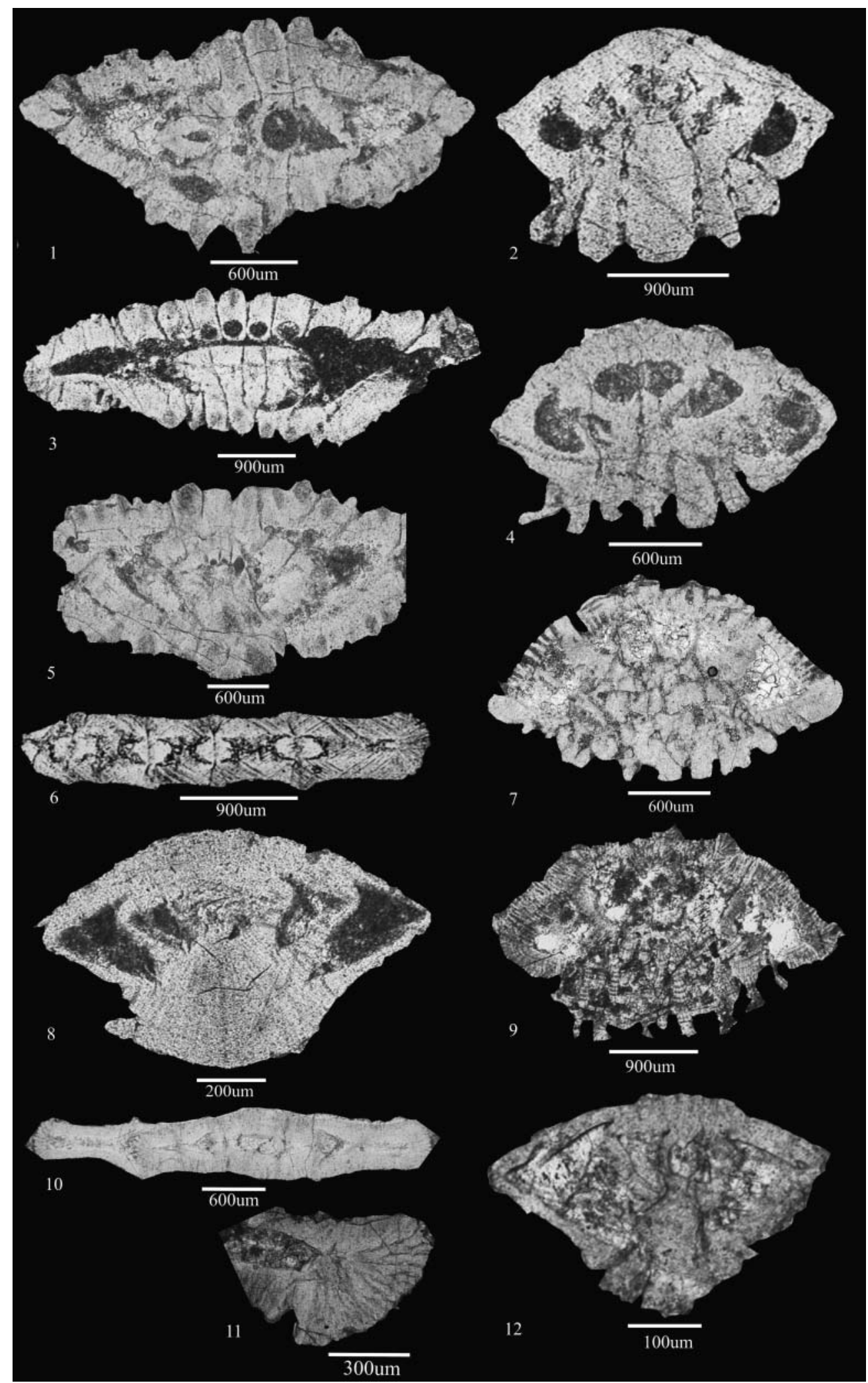

Explanation of Plate 1.

Biostratigraphically significant Thanetian shallow benthonic foraminifera of the Lockhart Formation from the Kotal Pass section of the Kohat area (Upper Indus Basin). figs 1, 3, 5. Miscellanea miscella D'Archiac \& Haime, 1853: 1, 5, megalospheric form, axial section; 3, microspheric form, off-centre axial section. figs 2, 4. Lockhartia conditi Nuttall, 1926, axial section. fig. 6. Operculina jiwani Davies \& Pinfold, 1937, off-centre axial section. figs 7, 9. Lockhartia haimei Davies, 1927, axial section. fig. 8. Kathina selveri Smout, 1954, axial section. figs 10, 11. Ranikothalia sindensis Davies, 1927: 10, microspheric form, axial section; 11, marginal cord, axial section. fig. 12. Rotalia trochidiformis Lamarck, 1804, axial section. 
Meissner et al. (1974). Weiss (1993) reported larger benthonic foraminifera from the Kohat area of intermediate biostratigraphical age between Zones SBZ10 and SBZ17. Similarly, Assilina exponens, reported by Akhtar \& Butt (2001), also ranges in age from Zones SBZ13 to SBZ17. These foraminiferal occurrences and the regional stratigraphical position imply a biostratigraphical range of SBZ14 to SBZ16 for the Kohat Formation (Fig. 4).

\section{THE LOWER INDUS BASIN}

The early Palaeogene sediments of the Lower Indus Basin were deposited on a broad shelf area of the passive continental margin of the Indo-Pakistan Plate (Bannert, 1992). The history of stratigraphical nomenclature for the Lower Indus Basin is given in Table 3 and the biostratigraphical framework in Figures 5 and 6. A regional stratigraphical correlation with the Upper Indus Basin is given in Figure 7. Early Palaeogene marine sediments are well exposed across the basin (Fig. 2B). The context for the different stratigraphical units from key sections is discussed below.

\section{The Sulaiman Range and Kirthar Range}

The Sulaiman Range forms a lobate structure in the northern part of the Lower Indus Basin, while the Kirthar Range forms a north-south linear feature in the southern region (Figs 1, 2B). The succession in the Sulaiman and Kirthar ranges has been studied since the nineteenth century.

The Dungan Formation of Kazmi (1995) marks the basal lithological unit of the lower Tertiary and unconformably overlies Late Cretaceous units in most of the Lower Indus Basin. It equates to the Khadro, Bara, Lakhra and Dungan formations of Shah (1977). The lowermost sandstone, siltstone and shale portion (Khadro Formation of Shah, 1977) of the formation is widely developed in the Kirthar Range, but rare or absent in the Sulaiman Range (e.g. Rakhi Nala). It has yielded planktonic foraminifera of Zone P1 (Nagappa, 1959) (Figs 5, 6). The overlying sandstone/siltstone unit (Bara Formation of Shah, 1977) of the lower Dungan Formation is widely distributed in the Kirthar Range, but rare in the Sulaiman Range. It lacks age-diagnostic fossils (Shah, 1977; Afzal, 1996; Wakefield \& Monteil, 2002). The upper Dungan Formation (the Lakhra and Dungan formations of Shah (1977) and Bara and Lakhra members of Wakefield \& Monteil (2002)) is dominantly limestone and shale, and is well developed in the Sulaiman and Kirthar ranges. Many biostratigraphically important larger benthonic foraminifera from the formation include Miscellanea miscella, Discocyclina ranikotensis, D. dispansa, Lockhartia haimei, Alveolina sp., Ranikothalia nuttalli and Assilina dandotica (in Shah, 1977; Weiss, 1993; Akhtar \& Butt, 2000; Wakefield \& Monteil, 2002), which suggest an age of late Thanetian to early Ilerdian. The nannofossil Zones NP4, NP7 and NP9 (Köthe et al., 1988) and planktonic foraminiferal Zones P7 (Afzal, 1996) and P3-P7 (Jones, 1997; Warraich et al., 2000) further support a Middle Paleocene-Early Eocene age. The upper contact of the formation with the overlying Ghazij Formation has been interpreted as conformable in most of the basin (Shah, 1977, 1990;
Kazmi, 1995); however, Warraich et al. (2000) reported Zone P6-lower P7? to be missing, with a conglomeratic bed between these formations in the northwestern Sulaiman Range (Rakhi Nala and Zinda Pir areas), suggesting this relationship to be unconformable (Figs 6, 7).

The Ghazij Formation, as recognized here, corresponds to the Ghazij and Laki formations of Shah (1977), the Laki Formation of Wakefield \& Monteil (2002) and the Ghazij Group of Shah (1990) and Kazmi (1995). It is dominantly shale with subordinate claystone, sandstone, limestone, coal and conglomerate. The formation is well developed in the Sulaiman Range and parts of the Kirthar Range (Shah, 1977). Early biostratigraphical ages determined from rich occurrences of larger benthonic foraminifera, e.g. Assilina leymeriei, A. pustulosa, Orbitolites complanatus, Nummulites globulus, etc. (equivalent to Zones SBZ8-SBZ13) (Eames, 1952; Nagappa, 1959) were later confirmed by Weiss (1993) and Wakefield \& Monteil (2002). Planktonic foraminiferal biostratigraphical ages were first investigated by Latif (1964) and Samantha (1973) and later by Afzal (1996), who supported an age range of Zones P7-P9. This assignment has recently been confirmed by the detailed work of Wakefield \& Monteil (2002) and Warraich \& Nishi (2003), who reported a continuous record of planktonic Zones P7 to P10? (Figs 5, 6). Planktonic foraminiferal studies also show a gap spanning upper P10? to P11 in the upper part of the Ghazij Formation to the lower part of the Kirthar Formation in the western Sulaiman Range (Warraich \& Nishi, 2003) (Figs 5, 6). However, Köthe et al. (1988) reported dinoflagellate Zone Pak-DIX (equivalent to nannofossil Zones NP12-lower NP14) from the upper part of the formation and Pak-DX to Pak-DXI (equivalent to upper NP14-NP19/20) from the overlying Kirthar Formation of Shah (1977) (Figs 5, 6). These results suggest a conformable relationship between the Ghazij and Kirthar formations in the western Lower Indus Basin; however, this relationship is unconformable in the eastern Lower Indus Basin with a c. 2 million-year hiatus, with Zone P11 absent (Wakefield \& Monteil, 2002) (Figs 6, 7).

The Kirthar Formation consists of limestone and shale with minor marl (Shah, 1977). The formation is widely distributed in the Sulaiman-Kirthar ranges and is richly fossiliferous with many age-diagnostic fossils (Shah, 1977). Based on the foraminiferal records of the Hunting Survey Corporation (1960), Shah (1977) assigned a broad stratigraphical range of Ypresian-Priabonian. However, other foraminiferal studies have given an age of late Lutetian-early Priabonian based on occurrences of planktonic foraminiferal species indicative of Zone P14 (Latif, 1964) and of Zones P12-P13 and P15-P17 (Samantha, 1973). Warraich \& Nishi (2003) and Wakefield \& Monteil (2002) recently established the presence of a continuous record of Zones P12 to P15? (Figs 6, 7). The lower part of the Kirthar Formation is rich in larger benthonic foraminifera, including Assilina spinosa, A. exponens, A. cancellata, Nummulites beaumonti and Discocyclina sowerbyi, equivalent to Zones SBZ13-SBZ18 (Eames, 1952; Nagappa, 1959; Weiss, 1993), suggesting a shallow-marine environment, which may account for the gap in the planktonic foraminiferal records. The Kirthar Formation is mostly overlain by Miocene-Pliocene age molasse sediments of the Siwalik Group (Shah, 1977). 


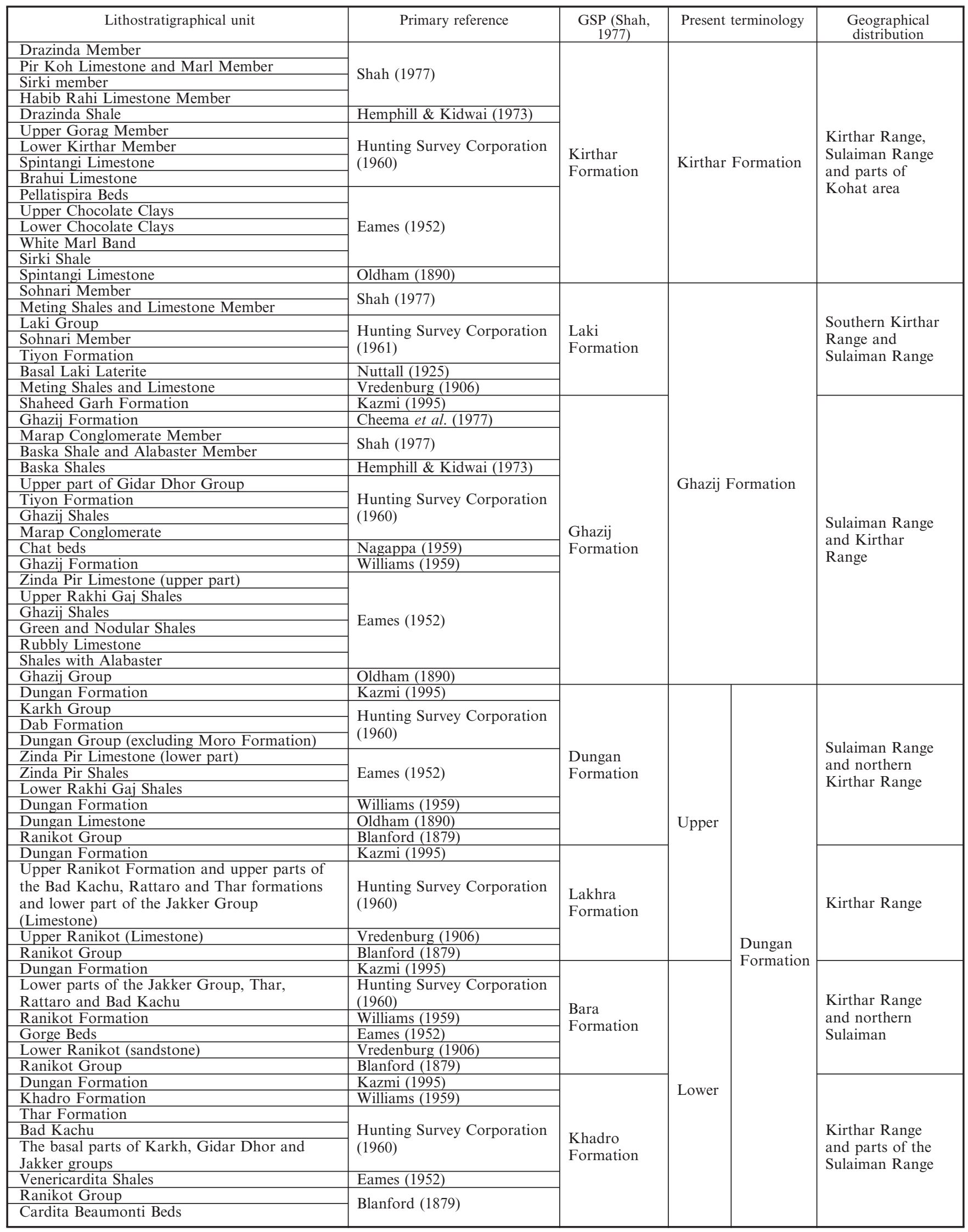

Table 3. Lithostratigraphical nomenclature of the Lower Indus Basin, Pakistan. 


\section{REGIONAL STRATIGRAPHICAL CONTEXT}

The lower Cenozoic succession of the Greater Indus Basin in Pakistan is characterized by considerable changes in lithologies and fauna. Inter-regional stratigraphical correlations for the Greater Indus Basin in Pakistan are given in Figure 7 and are related to global sea-level variations and biochronostratigraphy.

The earliest marine Cenozoic sedimentation in the basin seems to have commenced with the Paleocene transgression (Haq et al., 1987). The continental near-shore facies of the Hangu Formation initially dominated in the north-northwestern parts of the basin (Hazara Range, Kala Chitta Range and Kohat area) (Latif, 1976; Köthe et al., 1988; Weiss, 1993; Akhtar \& Butt, 1999). Southwestwards, into the Surghar and Salt ranges, it extended into shallow-marine deltaic facies, with coal and marine fossils (Shah, 1977; Warwick et al., 1993), and further south into the correlative planktonic and smaller benthonic foraminifera-bearing lower Dungan Formation (= Cardita Beaumonti Beds in Nagappa, 1959) (Figs 6, 7). This marine flooding was succeeded by widespread carbonate platform deposition of the Lockhart Formation in the Upper Indus Basin and upper Dungan Formation (= Bara and Lakhra members of Wakefield \& Monteil, 2002) in the Lower Indus Basin. The correlative planktonic foraminifera-bearing shales of the Dungan Formation in the northwestern Sulaiman Range (e.g. Rakhi Nala and Zinda Pir areas) were deposited in an openmarine environment (Warraich et al., 2000). These carbonates recorded the first expansion of lower Cenozoic shallow benthonic larger foraminifera in the basin (Weiss, 1993; Akhtar \& Butt, 1999; Warraich et al., 2000; Wakefield \& Monteil, 2002; Afzal et al., 2005); these preferentially flourished in oligotrophic conditions (Hottinger, 1997) (Figs 4, 6). The carbonate platform was buried by deep-marine clastics of the Patala Formation (= P4c-P6) in most of the Upper Indus Basin and by the shales of the Ghazij Formation (= P7-P10) in parts of the Lower Indus Basin. The hiatus equivalent to Zones upper P5-P6a in the northern Upper Indus Basin (Kala Chitta and Hazara ranges; Akhtar \& Butt, 1999, 2001) and P6-lower P7? in the western (Zinda Pir area; Warraich et al., 2000) and P6b-lower P7 in the eastern (Duljan-1 Well; Wakefield \& Monteil, 2002) parts of the Lower Indus Basin may have been caused by compression, uplift and erosion associated with India-Asia collision (around $55 \mathrm{Ma}$; Klootwijk et al., 1991; Beck et al., 1995; Warraich \& Nishi, 2003) (Fig. 7). These events were accompanied by highly significant stratigraphical changes in parts of the basin, for example, producing intermittent shallow- and deep-marine sediments (Weiss, 1993; Afzal \& Butt, 1999; Warraich et al., 2000) and dramatic shifts from marine to continental deposits, the latter containing endemic mammal occurrences (Clyde et al., 2003). The Paleocene/Eocene boundary has been established in the basin through the identification of planktonic foraminiferal Zones P5/P6 (Afzal \& Butt, 2000; Warraich et al., 2000), larger benthonic foraminiferal assemblages (Weiss, 1993; Akhtar \& Butt, 1999), and nannofossil Zones NP9/NP10 (Köthe et al., 1988) (Figs 3-6).

The open-marine planktonic foraminifera of the lower Cenozoic successions of the Greater Indus Basin in Pakistan show abrupt changes in composition, for example there was an increase in tropical-subtropical species of the morozovellid group during P4-P5 zones followed by a decrease in morozovellids and an increase in cooler-water species of subbotinid group foraminifera during Zones P6-P7 (Afzal \& Butt, 2000; Warraich et al., 2000; Warraich \& Nishi, 2003). The shallow-marine benthonic foraminiferal communities of the Greater Indus Basin in Pakistan experienced a significant diversification of species near the Paleocene-Eocene boundary; Thanetian-earliest Ilerdian (= SBZ4-SBZ6?) small species, including Miscellanea, Ranikothalia and Lockhartia, were succeeded by early Ilerdian (= SBZ6-SBZ8) large species of Nummulites, Discocyclina, Alveolina and Assilina (Weiss, 1993; Akhtar \& Butt, 1999, 2000; Sameeni \& Butt, 2004). These marine faunal changes in the region during the late Thanetian-early Ypresian may have been associated with long-term global warming events of the lower Cenozoic (Kelly et al., 1996; Zachos et al., 2001; Scheibner et al., 2005)

The Ypresian-early Lutetian (P7-P10) sediments show a shallowing-upward sequence, associated with the YpresianLutetian marine transgression-regression (Haq et al., 1987) (Figs 4, 6, 7). In the northeast (Kala Chitta, Hazara, Salt and Surghar ranges), these sediments comprise carbonate-rich units (Margala Hill Formation/Nammal Formation; Shah, 1977; Akhtar \& Butt, 1999; Afzal \& Butt, 2000) and in the northwest (Kohat area) a mudstone/shale-rich unit (Panoba Formation; Köthe et al., 1988; Weiss, 1993) and a carbonate-rich unit (Shekhan Formation; Köthe et al., 1988; Weiss, 1993). The higher parts of the succession include evaporites (= the Bahadar Khel Salt-Jatta Gypsum; Shah, 1977) and finally the continental red bed/sandstone mammal-bearing Kuldana Formation (Gingerich, 2003) (Figs 4, 7). The mammals of the upper Subathu Formation or Kalakot Zone of India (stratigraphically coeval to the Kuldana Formation; Sahni \& Jolly, 1993) are comparable with the mammals of the Kuldana Formation (Sahni \& Jolly, 1993; Gingerich, 2003). The marine regression is also recognizable in the south-southwestern parts of the basin (Lower Indus Basin), where the Ghazij Formation developed gypsum-rich, coal- and mammal-bearing beds (Clyde et al., 2003) (Figs 6, 7). The mammal taxa from the Ghazij Formation indicate a pattern of decreasing endemism, increasing cosmopolitanism and increasing modernity through time (= P7-lower P9; Clyde et al., 2003). This suggests a bridging contact of the Indian plate with the Asian plate in parts of the northwestern Lower Indus Basin, which was broken up by marine deposition of limestone and shale of the upper Ghazij and lower Kirthar formations during early Lutetian time (Johnson et al., 1999). The shale and carbonates of the Sakesar Formation, a marine correlative of the Kuldana Formation in the western Salt Range and Surghar Range, is overlain by Miocene-Recent terrestrial sediments derived from the Himalaya (Shah, 1977), marking the closure of Tethys in the southeastern Upper Indus Basin (Figs 4, 7).

The late Lutetian-Priabonian regression (Haq et al., 1987) is represented by the upper Kirthar Formation in the southsouthwest and the correlative uppermost Kohat Formation in the north-northwest. This followed closure of the Tethys in the north-northwestern parts of the basin (e.g. Kohat area, Kala Chitta and Hazara ranges) (Figs 4, 6, 7). The gradual retreat of the Tethys Sea continued south-southwest through late Lutetian to Bartonian time and it finally closed in the Priabonian (P15; Warraich et al., 2000; Wakefield \& Monteil, 2002). Oligocene 
marine sedimentation was restricted to the south of the Lower Indus Basin (Raza, 2001a), while the rest of the Greater Indus Basin in Pakistan remained a non-depositional lowland until the formation of Neogene molasse (Shah, 1977; Raza, 2001a).

\section{CONCLUSIONS}

The lower Cenozoic succession of the Greater Indus Basin in Pakistan preserves an excellent sedimentary and biotal record of the east Tethyan Sea. These provide significant stratigraphical evidence of locally and globally significant geologically important events.

The succession is dominated by shallow-marine shelf sediments intermixed with deep-marine sediments rich in stratigraphically important microbiota. Previously published stratigraphical data have been reinterpreted and many stratigraphical levels have been revised. In addition, biostratigraphically significant shallow benthonic foraminifera from the Lockhart Formation are illustrated. Inter-basinal correlations between various units and with the global standard biostratigraphy and chronostratigraphy are presented. These have enabled recognition of unconformities associated with ongoing India-Asia tectonics and global sea-level change about $55 \mathrm{Ma}$ ago. The closure of Tethys was initiated from the north and northwest during early Lutetian time and was completed by the Priabonian in the south and southwest. This also implies that the Indian Plate came in contact with the Asian Plate in the north first, and later in the southwest, which resulted in the closure of the Tethys Sea and cessation of sedimentation in the basin.

\section{ACKNOWLEDGEMENTS}

The authors would like to thank Professor Robert Speijer (Katholieke University, Leuven, Belgium) and Dr Matthew Wakefield (BG Group) for their constructive reviews of this paper. They are grateful to the Higher Education Commission of Pakistan and the Department of Geology, University of Leicester, UK for sponsoring these studies. Professor M. Asif Khan and Dr Fazl Rabbi Khan (National Centre of Excellence in Geology, University of Peshawar, Pakistan) are thanked for organizational support given during the entire course of these studies. Thanks also go to Yousaf Haroon and M. Ashraf Khan of the GSP, Peshawar, for their assistance with fieldwork. Mohibullah (Baluchistan University, Pakistan), Hamid Afridi (Oil and Gas Development Company Ltd, Pakistan), Khan Zeb Jadoon (University of Peshawar) and Ishtiaq Noor (Hydrocarbon Development Institute of Pakistan, Islamabad) are thanked for providing literature. Jawad Afzal also thanks The Micropalaeontological Society for a grant for fieldwork, NERC and The John Whitaker Fund of the Department of Geology, University of Leicester, UK, for support.

\section{Manuscript received 5 June 2008 Manuscript accepted 9 January 2009}

\section{REFERENCES}

Afzal, J. 1996. Late Cretaceous to Early Eocene foraminiferal biostratigraphy of the Rakhi Nala area, Sulaiman Range, Pakistan. Pakistan Journal of Hydrocarbon Research, 8: 1-24.
Afzal, J. \& Butt, A.A. 2000. Lower Tertiary planktonic biostratigraphy of the Salt Range, Northern Pakistan. Neues Jahrbuch für Geologie und Paläontologie, Monatshefte, 2000: 721-747.

Afzal, J. \& Daniels, C.H.V. 1991. Foraminiferal biostratigraphy and paleoenvironmental interpretation of the Paleocene to Eocene Patala and Nammal Formations from Khairabad-East, Western Salt Range, Pakistan. Pakistan Journal of Hydrocarbon Research, 3: 61-79.

Afzal, J., Khan, F.R., Khan, S.N., Alam, S. \& Jalal, M. 2005. Foraminiferal biostratigraphy and paleoenvironments of the Paleocene Lockhart Limestone from Kotal Pass, Kohat, Northern Pakistan. Pakistan Journal of Hydrocarbon Research, 15: 9-24.

Akhtar, M. \& Butt, A.A. 1999. Lower Tertiary biostratigraphy of the Kala Chitta Range, northern Pakistan. Revue de Paléobiologie, Genéve, 18: 123-146.

Akhtar, M. \& Butt, A.A. 2000. Significance of Miscellanea miscella (D'Archiac \& Haime) in the Early Paleogene stratigraphy of Pakistan. Revue de Paléobiologie, Genéve, 19: 123-135.

Akhtar, M. \& Butt, A.A. 2001. The Paleogene of the Kala Chitta Range, northern Pakistan. Neues Jahrbuch für Geologie und Paläontologie, Monatshefte, 1: 43-55.

D’Archiac, V.E.J.A.D. \& Haime, J. 1853. Description des Animaux fossiles du Groupe nummulitique de l'Inde. Précédé d'un résumé géologique et d'une monographie des Nummulites, Paris, 2:1-373.

Arenillas, I., Molina, E., Ortiz, S. \& Schmitz, B. 2008. Foraminiferal and $\delta 13 \mathrm{C}$ isotopic event-stratigraphy across the Danian-Selandian transition at Zumaya (northern Spain): chronostratigraphic implications. Terra Nova, 20(1): 38-44.

Bannert, D. 1992. The structural development of the western fold belt. Geologisches Jahrbuch, B80: 3-60.

Beck, R.A., Burbank, D.W. \& Sercombe, W.J. et al. 1995. Stratigraphic evidence for an early collision between northwest India and Asia. Nature, 373: 55-58.

Berggren, W.A., Kent, D.V., Swisher, C.C. \& Aubry, M.P. 1995. A revised Cenozoic geochronology and chronostratigraphy. In: Berggren, W.A., Kent, D.V., Aubry, M.P. \& Hardenbol, J.A. (Eds), Geochronology, Time Scales and Global Stratigraphic Correlations: A Unified Temporal Framework for an Historical Geology. Society of Economic Paleontologists and Mineralogists, Special Volume, 54: 129-212.

Blanford, W.T. 1879. The geology of western Sind. Memoir of the Geological Survey of India, 17(1): 1-197.

Butler, R. 1995. When did India hit Asia? Nature, 373: 20-21.

Butt, A.A. 1991. Ranikothalia sindensis Zone in Late Paleocene biostratigraphy. Micropaleontology, 37: 77-85.

Cheema, M.R., Raza, S.M. \& Ahmad, H. 1977. Cainozoic. In: Shah, S.M.I. (Ed.), Stratigraphy of Pakistan. Memoir of the Geological Survey of Pakistan, 12: 1-138.

Clyde, W.C., Khan, I.H. \& Gingerich, P.D. 2003. Stratigraphic response and mammalian dispersal during initial India-Asia collision: Evidence from the Ghazij Formation, Balochistan, Pakistan. Geological Society of America Bulletin, 31: 1097-1100.

Cotter, G.de P. 1933. The geology of the part of the Attock district, west of longitude $72^{\circ} 45 \mathrm{E}$. Memoir of the Geological Survey of India, 55: 63-161.

Danilchik, W. \& Shah, S.M.I. 1987. Stratigraphy and coal resources of the Makarwal area, Trans-Indus Mountains, Mianwali District, Pakistan. United States Geological Survey Professional Paper, 1341: $1-38$.

Davies, L.M. 1927. The Ranikot beds at Thal (North-West Frontier Ranges of India). Quarterly Journal of the Geological Society of London, 83: 260-290.

Davies, L.M. 1930. The fossil fauna of the Samana Range and some neighbouring areas, the Paleocene foraminifera. Memoir of the Geological Survey of India, Paleontologia Indica, 15: 67-79.

Davies, L.M. \& Pinfold, E.S. 1937. The Eocene beds of the Punjab Salt Range. Memoir of the Geological Survey of India, 24: 1-79.

Dewey, J.F., Cande, S. \& Pitman, W.C. 1989. Tectonic evolution of the India/Eurasia collision zone. Eclogae Geologicae Helvetiae, 82: 717 734.

Eames, F.E. 1952. A contribution to the study of the Eocene in western Pakistan and western India; Part A. The geology of standard sections 
in the western Punjab and in the Kohat District. Quarterly Journal of the Geological Society of London, 107: 159-171.

Fatmi, A.N. 1974. Lithostratigraphic units of the Kohat-Potwar Range, Indus Basin, Pakistan. Memoirs of the Geological Survey of Pakistan, 10: $1-80$

Fermor, L.L. 1935. General report of the Geological Survey of India for the year 1934. Records of the Geological Survey of India, 69: 1-108.

Ferrandez-Canadell, C. 2002. New Paleocene orbitoidiform foraminifera from the Punjab Salt Range, Pakistan. Journal of Foraminiferal Research, 32: 1-21.

Gee, E.R. 1934. The Saline Series of north-western India. Current Science, 2: 460-463.

Gee, E.R. 1945. The age of the Saline Series of the Punjab and of Kohat Proceedings of the National Academy of Science India, 14: 269-310.

Gibson, T.G. 1990. Upper Paleocene foraminiferal biostratigraphy and paleoenvironments of the Salt Range, Punjab, Pakistan. United States Geological Survey Bulletin, 2078: 1-13.

Gingerich, P.D. 2003. Stratigraphic and micropaleontologic constraints on the middle Eocene age of the mammal-bearing Kuldana Formation of Pakistan. Journal of Vertebrate Paleontology, 23: 643-651.

Haq, B.U., Hardenbol, J. \& Vail, P.R. 1987. Chronology of fluctuating sea levels since the Triassic (250 million years ago to present). Science, 235: $1156-1167$.

Haque, A.F.M.M. 1956. The Foraminifera of the Ranikot and the Laki of the Nammal Gorge, Salt Range. Pakistan Geological Survey, Paleontologia Pakistanica, 1: 1-300.

Hemphill, W.R. \& Kidwai, A.H. 1973. Stratigraphy of the Bannu and Dera Ismail Khan areas, Pakistan. United States Geological Survey Professional Paper, 716-B: 1-36.

Hodges, K.V. 2000. Tectonics of the Himalayan and southern Tibet from two perspectives. Geological Society of America Bulletin, 112: 324-350.

Hottinger, L. 1997. Shallow benthonic foraminiferal assemblages as signals for depth of their deposition and their limitations. Bulletin de la Société Géologique de France, 168: 491-505.

Hunting Survey Corporation Ltd. 1960. Reconnaissance geology of part of West Pakistan, a Colombo Plan Cooperative Project. A report published for Government of Pakistan by Government of Canada. Maracle Press, Toronto, 1-550.

Johnson, E.A., Warwick, P.D., Roberts, S.B. \& Khan, I.H. 1999. Lithofacies, Depositional Environments, and Regional Stratigraphy of the Lower Eocene Ghazij Formation, Balochistan, Pakistan. US Geological Survey Professional Paper, 1599: 1-76.

Jones, R.W. 1997. Aspects of the Cenozoic stratigraphy of the Northern Sulaiman Ranges, Pakistan. Journal of Micropalaeontology, 16: $51-58$

Kazmi, A.H. 1995. Sedimentary sequence. In: Bender, F.K. \& Raza, H.A. (Eds), Geology of Pakistan. Gebruder Borntraeger, Stuttgart, 162-181.

Kelly, D.C., Bralower, T.J., Zachos, J.C., Premoli-Silva, I. \& Thomas, E. 1996. Rapid diversification of planktonic foraminifera in the tropical Pacific (ODP Site 865) during the Late Paleocene thermal maximum. Geology, 24: 423-426.

Kemal, A., Balkwill, H.R. \& Stoakes, F.A. 1992. Indus basin hydrocarbon plays. In: Ahmad, G., Kemal, A., Zaman, A.S.H. \& Humayon, M. (Eds), New Directions and strategies for accelerating petroleum exploration and production in Pakistan. Oil and Gas Development Corporation, Islamabad, 78-105.

Khan, A.M. \& Srivastava, S.K. 2006. The paleogeographic significance of Aquilapollenites occurrences in Pakistan. Journal of Asian Earth Sciences, 28: 251-258.

Khan, S.N. \& Ahmad, W. 1966. Geology of Langrial iron ore, Hazara District. Memoirs Geological Survey of Pakistan, 25: 1-15.

Klootwijk, C.T., Gee, J.S., Peirce, J.W. \& Smith, G.M. 1991. Constraints on the India-Asia convergence: Paleomagnetic results from Ninetyeast Ridge. Proceedings of the Ocean Drilling Program, Scientific Results, 121: 777-881.

Köthe, A., Khan, A.A. \& Ashraf, M. 1988. Biostratigraphy of the Surghar Range, Salt Range, Sulaiman Range and the Kohat area, Pakistan, according to Jurassic through Paleogene calcareous nanno- fossils and Paleogene dinoflagellates. Geologisches Jahrbuch, B71: $1-87$.

Lamarck, J.B. 1804. Suit des mémoires sur les fossiles environs de Paris. Annales Muséum National d'Histoire Naturelle, Paris, 5: 179-188.

Latif, M.A. 1964. Variations in abundance and morphology of pelagic Foraminifera in the Paleocene-Eocene of the Rakhi Nala, West Pakistan. Geological Bulletin of Punjab University, 4: 29-100.

Latif, M.A. 1970. Explanatory notes on the geology of southeastern Hazara to accompany the revised geological map. Jahrbuch der Geologischen Bundesanstalt, Sonderband, 15: 5-20.

Latif, M.A. 1976. Stratigraphy and micropaleontology of the Galis Group of Hazara, Pakistan. Geological Bulletin of Punjab University, 13: 1-64.

Le Fort, P. 1996. Evolution of the Himalaya. In: Yin, A. \& Harrison, M. (Eds), The Tectonic Evolution of Asia. Cambridge University Press, Cambridge, 95-109.

Le Pichon, X., Fournier, M. \& Jolivet, J. 1992. Kinematics, topography, shortening and extrusion in the India-Asia collision. Tectonics, 11: $1085-1098$

Luterbacher, H.P., Ali, J.R. \& Brinkhuis, H. et al. 2004. The Paleogene Period. In: Gradstein, F., Ogg, J. \& Smith, A. (Eds), A Geological Timescale 2004. Cambridge University Press, Cambridge, 384-408.

Martini, E. 1971. Standard Cenozoic and Quaternary calcareous nannoplankton zonation. Proceedings of the Second International Conference on Planktonic Microfossils Rome, 2: 739-777.

Meissner, C.R., Master, J.M., Rashid, M.A. \& Hussain, M. 1968. Stratigraphy of the Kohat quadrangle. United States Geological Survey, Project Report, PK-20: 1-86.

Meissner, C.R., Master, J.M., Rashid, M.A. \& Hussain, M. 1974. Stratigraphy of the Kohat quadrangle, West Pakistan. United States Geological Survey Professional Paper, 716-D: 1-75.

Middlemiss, C.S. 1896. The geology of Hazara and Black Mountain. Memoir of the Geological Survey of India, 26: 1-302.

Nagappa, Y. 1959. Foraminiferal biostratigraphy of the CretaceousEocene succession in the India-Pakistan, Burma region. Micropaleontology, 5: 145-192.

Nuttall, W.L.F. 1925. The stratigraphy of the Laki Series (Lower Eocene) of parts of Sind and Baluchistan (India); with a description of the larger foraminifera contained in those beds. Quarterly Journal of the Geological Society, 81: 337-373.

Nuttall, W.L.F. 1926. The larger foraminifera of the Upper Ranikot Series (Lower Eocene) of Sind, India. Geological Magazine, 63: $112-121$.

Oldham, R.D. 1890. Report on the geology and economic resources of the country adjoining the Sind-Pishin railway between Sharigh and Spintangi, and of the country between it and Khattan. Records of the Geological Survey of India, 23: 93-109.

Pascoe, E.H. 1920. Petroleum in the Punjab and North West Frontier Range. Memoir of the Geological Survey of India, 40: 341-493.

Pascoe, E.H. 1963. A manual of the geology of India and Burma. Government of India Press, Calcutta, 3: 2073-2079.

Pinfold, E.S. 1918. Notes on structure and stratigraphy in NW Punjab. Records of the Geological Survey of India, 49: 138-161.

Qayyum, M., Niem, A.R. \& Lawrence, R.D. 2001. Detrital modes and provenance of the Paleogene Khojak Formation in Pakistan: implications for early Himalayan orogeny and unroofing. Geological Society of America Bulletin, 133: 320-332.

Raza, S.M. 2001a. The Eocene red beds of the Kala Chitta Range (Northern Pakistan) and its stratigraphic implications on the Himalayan Foredeep Basin. Geological Bulletin, University of Peshawar, 34: 83-104.

Raza, S.M. 2001b. Stratigraphic chart of Pakistan. Geological Survey of Pakistan, Quetta, 1 sheet.

Rowley, D.B. 1996. Age of initiation of collision between India and Asia; a review of stratigraphic data. Earth and Planetary Science Letters, 145: 1-13.

Sahni, A. \& Jolly, A. 1993. Eocene mammals from Kalakot, Kashmir Himalaya: community structure, taphonomy and palaeobiogeographical implications. Kaupia, Darmstädter Beiträge zur Naturgeschichte, 3: 209-222. 
Samantha, B.K. 1973. Planktonic foraminifera from the PaleoceneEocene succession in the Rakhi Nala, Sulaiman Range, Pakistan. Bulletin of the British Museum (Natural History), Geology, 22: 421-482.

Sameeni, S.J. \& Butt, A.A. 2004. Alveolinid biostratigraphy of the Salt Range succession, Northern Pakistan. Revue de Paléobiologie, Genéve, 23(2): 505-527.

Scheibner, C., Speijer, R.P. \& Marzouk, A.M. 2005. Larger foraminiferal turnover during the Paleocene/Eocene Thermal Maximum and paleoclimatic control on the evolution of platform ecosystems. Geology, 33: 493-496.

Searle, M.P., Windley, B.F. \& Coward, M.P. et al. 1987. The closing of Tethys and tectonics of the Himalayas. Geological Society of America Bulletin, 98: 678-701.

Serra-Kiel, J., Hottinger, L. \& Caus, E. et al. 1998. Larger foraminiferal biostratigraphy of the Tethyan Paleocene and Eocene. Bulletin de la Société Géologique de France, 169: 281-299.

Shah, S.M.I. 1977. Stratigraphy of Pakistan. Memoirs of the Geological Survey of Pakistan, 12: 1-137.

Shah, S.M.I. 1990. Coal resources of Baluchistan. In: Kazami, A.H. \& Siddiqui, R.A. (Eds), Significance of the coal resources of Pakistan. Geological Survey of Pakistan/United States Geological Survey, Quetta/Reston, 63-93.

Siddiqui, Q.A. 2006. The ostracod genus Paijenborchella and some of its species in the Early Tertiary of Pakistan. Journal of Micropalaeontology, 25: 165-172.

de Sigoyer, J., Chavagnac, V. \& Blichert-Toft, J. et al. 2000. Dating the Indian continental subduction and collisional thickening in the northwest Himalaya, multichronology of the Tso Morari eclogites. Geology, 28: 487-490.

Smout, A.H. 1954. Lower Tertiary foraminifera of the Qatar Peninsula. Bulletin of the British Museum (Natural History), 9: 1-80.

Vredenburg, E.W. 1906. Nummulites douvillei, an undescribed species from Kachh with remarks on the zonal distribution of Indian Nummulites. Records of the Geological Survey of India, 34: 79-95.
Waagen, W. \& Wynne, A.B. 1872. The geology of Mount Sirban in the upper Punjab. Memoir of the Geological Survey of India, 9: 331-350.

Wakefield, M.I. \& Monteil, E. 2002. Biosequence stratigraphical and palaeoenvironmental findings from the Cretaceous through Cenozoic succession, Central Indus Basin, Pakistan. Journal of Micropalaeontology, 21: 115-130.

Wandrey, C.J., Law, B.E. \& Shah, H.A. 2004. Sembar Goru/Ghazij Composite Total Petroleum System, Indus and Sulaiman-Kirthar Geologic Ranges, Pakistan and India. United States Geological Survey Bulletin, 1: 1-20.

Warraich, M.Y. \& Nishi, H. 2003. Eocene planktonic foraminiferal biostratigraphy of the Sulaiman Range, Indus Basin, Pakistan. Journal of Foraminiferal Research, 33: 219-236.

Warraich, M.Y., Ogasawara, K. \& Nishi, H. 2000. Late Paleocene to Early Eocene planktonic foraminiferal biostratigraphy of the Dungan Formation, Sulaiman Range, Central Pakistan. Paleontological Research, 4: 275-301.

Warwick, P.D., Javed, S., Mashhadi, S.T.A., Shakoor, T., Khan, A.M \& Khan, A.L. 1993. Lithofacies and palynostratigraphy of some Cretaceous and Paleocene Rocks, Surghar and Salt Range Coal Fields, Northern Pakistan. United States Geological Survey Bulletin, 2096: $1-33$.

Weiss, W. 1993. Age assignments of larger foraminiferal assemblages of Maastrichtian to Eocene age in northern Pakistan. Zitteliana, 20: 223-252.

Williams, M.D. 1959. Stratigraphy of the Lower Indus Basin, West Pakistan. In: Proceedings of the 5th World Petroleum Congress, New York, Section 1, Paper 19: 377-394.

Wynne, A.B. 1873. Memoir on the geology of Kutch. Memoir of the Geological Survey of India, 9: 1-294.

Wynne, A.B. 1874. Observations on some features in the physical geology of the Outer Himalayan Region of the Upper Punjâb, India. Quarterly Journal of the Geological Society of London, 30: 61-80.

Zachos, J.C., Pagani, M., Sloan, L., Thomas, E. \& Billups, K. 2001. Trends, rhythms, and aberrations in global climate $65 \mathrm{Ma}$ to present. Science, 292: 686-693. 